\title{
IMPLEMENTASI PENDEKATAN CONTEXTUAL TEACHING AND LEARNING PADA PEMBELAJARAN QUR'AN HADITS
}

\author{
Suriadi \\ Fakultas Tarbiyah dan Ilmu Keguruan \\ Institut Agama Islam Sultan Mubammad Syafiuddin Sambas \\ Email:suriadisambas@gmail.com
}

Triyo Supriyatno

Universitas Islam Negeri Maulana Malik Ibrabim Malang

Email: Email:triyo@pai.uin-malang.ac.id

\section{Muhammad Walid}

Universitas Islam Negeri Maulana Malik Ibrabim Malang

Email:walidpgmi@gmail.com

\section{Abstract}

This article discusses the learning of the Qur'an with the approach of contextual teaching and learning. This research was conducted at the Islamic Junior High School Mubammadiyah Sejangkung Sambas Regency. The study focused on learning the Qur'anic Hadith. The aim of the research was to describe the contextual teaching and learning on: a) the implementation of the learning of the Qur'anic Hadith, b) the implications of learning the Qur'an Hadith, (c) the factors supporting and inhibiting the learning of the Hadith Qur'an. This research was designed with a qualitative approach. The subject of the research was the Hadith teacher and the students at the Islamic Junior High School Mubammadiyah. The results of the analysis show that the implementation of the learning of Qur' an Hadith with a contextual teaching and learning approach is achieved by conveying more actual, realistic, enjoyable material in the four forms of learning methods namely learning together, group discussion, Jigsaw, and peer teaching method. Implications of learning have a very positive impact on students, among others, students are more responsive to the material being delivered, the classroom atmosphere is more pleasant, the material being delivered is more actual, so that it can indirectly improve the quality of education in madrasah (Islamic junior high school). The supporting factors for the positive effects are as follows: (1) The ability of teachers, (2) the ability of students, (3) facilities and infrastructure; while the inhibiting factors in implementing this strategy are (1) the limitations of teachers, (2) the lack of facilities and infrastructure, and (3) the diverse psychological abilities and souls of students.

Keywords: Learning, Qur'an Hadist, Contetextual Training and Learning

\section{Abstrak}

Artikel ini membahas tentang pembelajaran qur'an hadits dengan pendekatan contextual teaching and learning. Penelitian ini dilakukan di madrasah Tsanawiyah Muhammadiyah Sejangkung Kabupaten Sambas. Kajian difokuskan pada pembelajaran qur'an hadits. Penelitian bertujuan untuk menguraikan pembelajaran contextual teaching and learning pada: a) implementasi pembelajaran Qur'an Hadits, b) implikasi pembelajaran Qur'an Hadits, (c) faktor pendukung dan penghambat pembelajaran Qur'an Hadits. Penelitian ini didesain dengan pendekatan kualitatif. Subjek penelitian guru Qur'an Hadits dan siswa di madrasah Tsanawiyah Muhammadiyah Sejangkung. Hasil analisis menunjukkan bahwa implementasi pembelajaran qur'an hadits dengan pendekatan contextual teaching and learning terwujud dilakukan dengan cara menyampaikan materi yang lebih aktual, lebih realistis, lebih menyenangkan dalam empat bentuk metode pembelajaran yaitu metode belajar kelompok (learning together), metode diskusi kelompok (group discussion), metode Jigsaw dan metode tutor sebaya (peer teaching). Implikasi pembelajaran memberikan dampak yang sangat positif terhadap siswa antara lain siswa lebih mudah 
menerima materi yang disampaikan, suasana kelas lebih menyenangkan, materi yang disampaikan lebih aktual, sehingga secara tidak langsung) dapat meningkatkan mutu pendidikan di madrasah. Sedangkan faktor pendukung (1) Kemampuan guru, (2) Kemampuan siswa, (3). Sarana dan prasarana. Sedangkan faktor penghambat dalam penerapan Pendekatanini adalah: (1) Keterbatasan guru, (2), Sarana dan prasarana yang kurang memadahi, (3) Kemampuan dan jiwa psikologis siswa yang beragam.

Kata Kunci : Pembelajaran, Qur'an Hadist, Contetextual Teaching and Learning

\section{Latar Belakang}

Umat manusia dalam sejarahnya telah menunjukkan betapa pentingnya pendidikan. Hal ini dapat ditelusuri sejak masa Rasul hingga masa sekarang kegiatan yang dilakukan Rasulullah seperti mengadakan ta'lim kepada para sahabatnya, guna mengetahui ajaran Islam, sehingga Rasul membuat komplek belajar Daru AlArqam ${ }^{1}$.

Sistem pendidikan nasional mempunyai tujuan sekaligus sebagai alat yang amat penting dalam perjuangan mencapai cita-cita dan mencapai tujuan bangsa Indonesia dalam mencerdaskan kehidupan bangsa Indonesia dan mengembangkan manusia Indonesia seutuhnya, yaitu mengembangkan potensi peserta didik agar menjadi manusia yang beriman dan bertakwa kepada Tuhan Yang Maha Esa, berakhlak mulia, sehat, berilmu, cakap, kreatif, mandiri, dan menjadi warga Negara yang demokratis serta bertanggung jawab (Undang-Undang Nomor 20 Tahun 2003) $)^{2}$.

Mengingat begitu besarnya dalam mencapai tujuan pembelajaran adalah peserta didik, maka setiap upaya pencarian alternatif pendekatan pembelajaran harus senantiasa berlandaskan pada kepentingan peserta didik belajar. Dengan kata lain,

\footnotetext{
1 Suwito, Sejarah Sosial Pendidikan Islam

(Kencana, 2005)

<https://books.google.co.id/books?id=zsyCNAAA CAAJ $>$.

2 Nur Hadiyanta, Penerapan Model Pembelajaran Contextual Teaching and Learning (CTL) Untuk Meningkatkan Hasil Belajar PKn',
}

alternatif pendekatan tersebut harus mencerminkan suatu upaya untuk mencari alternatif bagi kepentingan peserta didik untuk mempermudah dalam mencapai tujuan belajar. Karena bagaimana pun kegiatan proses pembelajaran tidak hanya menekankan kepada apa (materi) yang harus dipelajari anak didik (pemahaman konsepkonsep), akan tetapi lebih menekankan pada bagaimana peserta didik harus belajar (belajar mengalami) ${ }^{3}$. Untuk mencapai tujuan atau keberhasilan peserta didik belajar, paling tidak terdapat lima hal atau lima variabel utama yang harus mendapat perhatian, yaitu: (1) Guru harus melibatkan peserta didik secara aktif; (2) guru harus dapat menarik minat peserta didik dan perhatian peserta didik; (3) guru harus mampu membangkitkan motivasi peserta didik; (4) mengembangkan prinsip individualitas; dan (5) melakukan peragaan dalam proses pembelajaran ${ }^{4}$. Salah satu pendekatan pembelajaran yang ditawarkan dan dipandang dapat memenuhi kriteria tersebut di atas adalah melalui pendekatan contextual teaching and learning (pendekatan pembelajaran kontekstual) atau sering disingkat dengan CTL.

Pada saat ini, penerapan pembelajaran CTL (contextual teaching and learning) sering digalakkan dalam pelatihan-pelatihandengan

Jurnal Kependidikan: Penelitian Inovasi Pembelajaran, 43.1 (2013).

3 Ahmad Zayadi and Abdul Majid, Pembelajaran Pendidikan, 2011.

4 M U Usman, Menjadi Guru Profesional

(Remaja Rosdakarya, 1999)

<https://books.google.co.id/books?id=enpZNwA ACAAJ $>$. 
harapan memberikan pengaruh positif terhadap hasil belajar. Pendekatan CTL merupakan salah satu alternatif pendekatan pembelajaran yang mana pendidik memposisikan para siswa sebagai subjek, bukan sebagai objek pembelajaran ${ }^{5}$. Contextual teaching and learning adalah suatau pendekatan pembelajaran yang menekankan pada proses keterlibatan peserta didik secara penuh untuk dapat menemukan materi yang dipelajari dan menghubungkannya dengan situasi kehidupan nyata, sehingga mendorong mereka untuk menerapkannya dalam kehidupan mereka ${ }^{6}$.

Permasalahan yang dihadapi dan dirasakan pula oleh masyarakat Indonesia saat ini, dari kalangan pelajar hingga elite politik, mengindikasikan bahwa pendidikan agama dan moral yang diajarkan pada bangku sekolah/madrasah maupun perguruan tinggi, tidak memberikan dampak terhadap perubahan perilaku masyarakat Indonesia. Bahkan yang terlihat adalah banyaknya masyarakat Indonesia yang tak memiliki prinsip yaitu tidak sejalannya antara ucapan dan tindakan ${ }^{7}$.

Menurut E Mulyasa, pendekatan pembelajaran kontekstual adalah suatu pendekatan pembelajaran yang menekankan pada keterkaitan antara materi pembelajaran dengan dunia kehidupan peserta didik secara nyata, sehingga peserta didik mampu menghubungkan dan menerapkan

${ }^{5}$ Noor Alfu Laila, 'Pengaruh Pendekatan Ctl (Contextual Teaching and Learning) Terhadap Hasil Belajar Membaca Pemahaman Bahasa Indonesia Siswa Kelas Iv Sd', Jurnal Cakrawala Pendidikan, 3.3 (2009) <https://doi.org/10.21831/cp.v3i3.301>.

6 Wina Sanjaya, Pembelajaran Dalam Implementasi Kurikulum Berbasis Kompetensi (Kencana, 2006)

$<$ https://books.google.co.id/books?id=QL9hNwA ACAAJ $>$. kompetensi hasil belajar dalam kehidupan sehari-hari.

Pembelajaran kontekstual merupakan salah satu Pendekatanpembelajaran yang dibangun atas dasar asumsi bahwa knowledge is constructed by bumane. Atas dasar inilah, maka dikembangankan pendekatan pembelajaran konstruktivisme yang membuka peluang yang seluas-luasnya kepada peserta didik untuk memberdayakan diri. Karena dalam teori pendidikan modern, cara belajar yang terbaik adalah peserta didik mengkonstruksi sendiri secara aktif pemahamannya.

Oleh karena itu, dalam rangka penerapan pendekatan kontekstual ini, kebiasaan guru yang melakukan aktingdi 'panggung' kelas dan peserta didik hanya menonton apa yang diperankan guru, sudah saatnya harus diubah menjadi siswa yang aktif belajar, sedangkan guru hanya membimbing dari dekat ${ }^{9}$. Sejalan dengan konsep belajar yang harus menekankan pada aktivitas peserta didik (student centred activity), maka pendekatan pembelajaran kontekstual lebih menekankan adanya keterlibatan peserta didik secara aktif, sedangkan guru hanya berperan sebagai pemimpin (manager) belajar peserta didik dan membimbingnya ${ }^{10}$. Sebagai konsekuensinya, guru harus mampu mengkondisikan kegiatan pembelajaran yang dapat membangkitkan minat (interest) dan perhatian peserta didik. Dengan kata lain, guru harus mampu memotivasi mereka

7 Zaini Gunawan and Ainur Rahmah, 'PENDEKATAN CONTEXTUAL TEACHING AND LEARNING DAN APLIKASINYA DALAM PEMBELAJARAN PAI DI SEKOLAH', PEDAGOGIK: Jurnal Pendidikan, 6.2 (2019), 557-92.

${ }^{8}$ E Mulyasa, Kurikulum Yang Disempurnakan, Pengembangan Standar Kompetensi Dan Kompetensi Dasar (Bandung: Remaja Rosda Karya, 2006).

${ }^{9}$ Zayadi and Majid.

10 E Mulyasa, Menjadi Guru Profesional (Bandung: Remaja Rosda Karya, 2005). 
dalam rangka mencapai tujuan yang telah direncanakan, oleh karena guru sebagai pelaksana kegiatan belajar peserta didik.

Esensi pembelajaran contextual teaching learning adalah membantu siswa mengaitkan materi yang dipelajari dengan situasi dunia nyata mereka dan mendorong siswa membuat hubungan antara pengetahuan yang dimilikinya dengan penerapannya dalam kehidupan seharihari ${ }^{11}$.

Tsanawiyah

Madrasah

Muhammadiyah Sejangkung Kabupaten Sambas adalah salah satu lembaga pendidikan Islam. Semenjak diberlakukannya kurikulum berbasis kompetensi dan disempurnakan dengan Kurikulum Tingkat Satuan Pendidikan atau KTSP, madarsah ini mencoba menerapkan konsep pembelajaran kontekstual (contextual teaching and learning) dalam proses pembelajaran Qur'an Hadist kepada peserta didiknya.

Pendekatan pembelajaran kontekstual di terapkan pada proses pembelajaran mata pelajaran Qur'an Hadist dilatar belakangi oleh keperihatinan dengan kondisi proses pembelajaran yang terjadi, hanya melahirkan output yang kaya dengan gagasan akan tetapi sangat miskin dengan aplikasi. Madrasah ini merupakan madrasah yang berstatus swasta dibawah naungan Kementerian Agama. Berdasarkan observasi ditemukan beberapa tindakan yang membtuhkan perbaikan. Beberapa tindakan tersebut di antaranya dalam menggunakan media ajar, pendekatan, metode, dan model yang bervariasi agar proses pembelajaran tidak terlalu monoton pada pelaksanaanya.

11 Sri Widarti, Endah Peniati, and Priyantini Widiyaningrum, 'Pembelajaran Gallery Walk Berpendekatan Contextual Teaching Learning Materi
Penggunaan metode, dan media pembelajaran sangatlah penting, karena hal tersebut berpengaruh terhadap hasil belajar. Dengan memberikan tindakan berupa penerapan pembelajaran kontekstual atau contextual teaching and learning. Penerapan pembelajaran ini diharapkan memberikan nuansa baru yang menarik pada proses pembelajaran.

\section{Metode Penelitian}

Penelitian ini menggunakan pendekatan penelitian kualitatif. Sesuai dengan pendekatan dan rancangan penelitian yang digunakan, maka instrumen yang digunakan untuk mengumpulkan data adalah peneliti sendiri. Kehadiran peneliti pada penelitian kualitatif merupakan suatu keharusan. Karena penelitian jenis ini lebih mengutamakan temuan observasi yang dilakukan peneliti pada latar alami penelitian secara langsung. Penelitian dilaksanakan di Propinsi Kalimantan Barat dengan mengambil lokasi pada madrasah Tsanawiyah swasta sejangkung. Sumber data dalam penelitian kualitatif dapat diperoleh dari informan-informan kunci yang menjadi pelaku utama yakni guru Qur'an Hadist, kepala sekolah dan siswa.

Teknik pengumpulan data dalam penelitian kualitatif merupakan langkah strategis untuk menentukan dan mendapatkan data dilapangan secara alamiah. Hal ini disebabkan salah satu karakteristik penelitian kualitatif adalah natural setting, yaitu ketika semua informasi yang dikumpulkan tentang realitas atau fenomena disusun dalam bentuk deskripsi verbal atau kata-kata ${ }^{12}$.

Sistem Pencernaan Di Sma', Journal of Biology Education, 2.1 (2013).

${ }^{12} \mathrm{~J}$. McMillian and S. Schumacher, Research in Education: A Conceptual Introduction (4th Edition). ., 
Mengingat data bersifat natural setting, maka teknik pengumpulan data lebih banyak pada observasi berperan serta (partisipant observation), wawancara mendalam (in depth interview) dan dokumentasi. Hal ini diungkapkan Catherine Marshall, Gretchen B. Rossman dalam Sugiyono ${ }^{13}$ menyatakan "the fundamental methods relied on by qualitative reserchers for gathering information are, participation in the setting, direct observation, in depth interviewing, document review". Adapun teknik pengumpulan data seperti wawancara observasi berperanserta, dan studi dokumentasi.

Penelitian ini menggunakan analisis data kasus individu (individual cases). Langkah-langkah analisis data yang dilakukan bersama-sama dengan pengumpulan data dan mengikuti petunjuk Miles \& Huberman (1992) yaitu (1) reduksi data, (2) penyajian data dan (3) kesimpulan (kesimpulan sementara, verifikasi dan kesimpulan akhir). Penelitian kualitatif memiliki karakteristik tersendiri dalam mengecek keabsahan data. ${ }^{14}$

\section{Pembahasan dan Temuan}

Pearson Education Limited (Scott, Foresman, 1997) $<$ https:/ / books.google.co.id/books?id=7J7kAAAA CAAJ $>$.

13 Sugiyono, Metodologi Penelitian Pendidikan; Pendekatan Kuantitatif Kualitatif Dan R\&D (Bandung: Alpabeta, 2009).

$14 \mathrm{R}$ Bogdan and S K Biklen, Qualitative Research for Education: An Introduction to Theory and Methods (Allyn and Bacon, 1992)
Implementasi

Pendekatan pembelajaran contextual teaching and learning Pembelajaran Qur'an Hadist

Pendekatan dapat diartikan sebagai titik tolak atau sudut pandang terhadap proses pembelajaran.

Salah satu cara untuk merubah pengajaran menjadi lebih efisien dan efektif adalah menggunakan Pendekatancontextual teaching learning. Menurut Goldstein (2004), contekstual teaching learning merupakan hal utama dalam pembelajaran efektif yaitu teks yang dirancang untuk mempersiapkan para siswa, pengajar, dan para pendidik guru berkesempatan memahami bagaimana contekstual teaching learning mampu mengubah suasana kelas dan programprogram pendidikan guru ${ }^{15}$. Contekstual teaching learning juga merupakan Pendekatanpembelajaran yang menekankan pada proses keterlibatan siswa secara penuh untuk dapat menemukan materi yang dipelajari dan menghubungkannya dengan situasi kehidupan nyata sehingga mendorong siswa dapat menerapkan dalam kehidupan mereka.

Secara etimologis kata kontekstual berasal dari bahasa Inggris, contextual, yang berarti mengikuti konteks atau dalam konteks. Secara umum kata contextual berarti, sesuatu yang berkenaan, relevan, ada hubungan atau kaitan langsung, mengikuti konteks; atau sesuatu yang membawa

$<$ https://books.google.co.id/books?id=1B4mAQA AIAAJ $>$.

15 Musepini Apriliani Panjaitan and Mufti Sudibyo, 'Perbandingan Hasil Belajar Siswa Yang Diajar Dengan Strategi Pembelajaran Contekstual Teaching Learning (CTL) Dengan Yang Diajar Dengan Strategi Pembelajaran Ekspositori Pada Materi Sistem Transportasi Darah SMP Swasta PAB 9 TP 2014/2015', Jurnal Pelita Pendidikan, 3.4 (2015). 
maksud, makna dan kepentingan ${ }^{16}$. Sedangkan secara terminologis, pembelajaran kontekstual (contextual teaching and learning) adalah suatu pendekatan pembelajaran yang menekankan pada proses keterlibatan siswa atau peserta didik secara penuh untuk dapat menemukan materi yang dipelajari dan menghubungkannya dengan situasi kehidupan nyata, sehingga mendorong siswa untuk dapat menerapkannya dalam kehidupan mereka ${ }^{17}$.

Pendekatan pembelajaran kontekstual merupakan rancangan pembelajaran yang dibangun atas dasar asumsi bahwa knowledge is constructed by bumane. Atas dasar itu, dikembangkan pendekatan pembelajaran konstruktivis yang membuka peluang seluas-luasnya kepada siswa untuk memberdayakan diri. Menurut pengertian ini, bahwa cara belajar yang baik adalah siswa mengkonstruksi sendiri secara aktif pemahamannya $^{18}$. Atau dengan kata lain, guru bukan hanya sekedar transfer of knowledge, tetapi lebih mementingkan Pendekatanpembelajaran daripada hasil.

Pemahaman tersebut di atas, dengan Dalam pendekatan ini, proses pembelajaran berlangsung secara alamiah dalam bentuk kegiatan siswa bekerja dan memahami. Kegitan ini merubah paradigma belajar, dari yang biasanya guru akting di panggung dan siswa atau peserta didik menonton, menjadi siswa aktif bekerja dan belajar di panggung, sedangkan guru membimbingnya dari dekatpendekatan kontekstual, maka peran guru adalah membantu siswa dalam mencapai tujuan pembelajaran. Guru lebih banyak berurusan dengan Pendekatandari pada memberi informasi. Tugas guru adalah mengelola kelas sebagai sebuah tim yang

${ }^{16}$ John M. Echols dan Hasan Syadily, Kamus Inggris Indonesia, Jakarta, Gramedia. (Jakarta: Gramedia, 2000). bekerja bersama untuk menemukan pengetahuan dan keterampilan yang baru bagi siswa. Pengetahuan dan keterampilan diperoleh dengan menemukan sendiri.

Madrasah Tsanawiyah Muhammadiyah Sejangkung Kabupaten Sambas yang merupakan bentuk pengembangan dari kurikulum yang secara nasional mengacu dibawah kurikulum Kementrian Agama Republik Indonesia. Bentuk pengembangan yang dilakukan berdasarkan pada visi dan misi di madrasah Tsanawiyah Muhammadiyah Sejangkung Kabupaten Sambas, yang disesuaikan dengan kebutuhan perkembangan belajar siswa.

Berdasarkan hasil observasi yang dilakukan oleh peneliti, penyampaian materi Qur'an Hadist yang diberikan di madrasah Tsanawiyah Muhammadiyah Sejangkung menerapkan tiga Pendekatanpembelajran, yang salah satu diantaranya adalah contextual teaching and learning (CTL), sehingga suasana di dalam kelas lebih menyenangkan dengan harapan siswa dapat mudah menerima materi yang disampaikan, dan menerapkannya dalam kehidupan nyata.

Pada dasarnya materi pendidikan yang diberikan di madrasah Tsanawiyah Muhammadiyah Sejangkung tidak jauh beda dengan materi yang ada di sekolah-sekolah pada umumnya, hanya saja di madrasah Tsanawiyah Muhammadiyah Sejangkung dalam penyampaian materi Qur'an Hadist penerapan pembelajaran yang di gunakan adalah contextual teaching and learning. $\mathrm{Hal}$ ini dikarena siswa siswi madrasah Tsanawiyah Muhammadiyah Sejangkung Beragama Islam, dan berada di lingkungan Muslim. Setelah guru Qur'an Hadist lama

\footnotetext{
${ }^{17}$ Sanjaya.

18 Zayadi and Majid.
} 
menggunakan model Konvensional, dan tidak ada perubahan yang signifikan maka diubahlah model pembelajaran tersebut dengan Model CTL.

Pengajaran Qur'an Hadist di madrasah Tsanawiyah Muhammadiyah Sejangkung menggunakan Pendekatanpembelajaran contextual teaching and learning sebagaimana telah dijelaskan oleh bapak wardi selaku guru Qur'an Hadist dan juga waka kurikulum di Tsanawiyah Muhammadiyah, sebagai berikut:

"Sistem pembelajaran yang kami lakukan adalah dengan tiga model cara yakni konvensional, CTL, dan diskusi/praktek. Sistem konvensional ini adalah sistem yang digunakan oleh guru yang kemudian guru menunjuk muridnya untuk menerangkan sesuai dengan batasan-batasannya Kemudian sistem CTL adalah murid diperbolehkan untuk memilih bagaimana belajar yang disukai juga dianggap mampu untuk dipraktekan sesuai dengan tingkatan dan kenyataan masing-masing dan untuk diskusi kami berikan sebuah permasalahaan yang ada sangkut pautnya dengan bab yang dibahas yang diajarkan kemudian siswa disuruh untuk mendiskusikan permasalahan tersebut sampai pada akhir pembelajaran guru memberikan kesimpulan."19

Dengan demikian dapat diambil kesimpulan bahwa Pendekatanpembelajaran aqidah akhlak yang diterapkan di madrasah Tsanawiyah Muhammadiyah Sejangkung, menggunakan tiga Pendekatan yakni PendekatanKonvensional, CTL, diskusi atau praktek. Akan tetapi, guru aqidah akhlak lebih sering menggunakan PendekatanCTL dikarenakan suasana kelas lebih menyenangkan, lebih aktual, lebih realistis, sehingga siswa lebih mudah menerima materi yang disampaikan.

Dalam meningkatkan mutu pendidikan Agama kepala sekolah madrasah Tsanawiyah Muhammadiyah Sejangkung memberikan dukungan terhadap pelaksanaan dan digunakannya pembelajaran Model contextual teaching and learning demi tercapainya tujuan pendidikan yang telah ditetapkan. Dengan diterapkannya pembelajaran model ini guru agama akan termotivasi untuk memberikan metode pembelajaran yang terbaik salah satunya dengan cara membangun minat siswa-siswi dengan menerapkan CTL, sebagaimana dijelaskan oleh Bapak Hendra, selaku Kepala Sekolah di madrasah Tsanawiyah Muhammadiyah Sejangkung, sebagai berikut:

"Cara yang di lakukan agar para siswa tidak jenuh dalam belajar agama adalah bagaimana kita pandai membangun minat pada siswa itu sendiri. Karena medel pembelajaran apapun kalau tidak ada minat dari siswa itu sendiri proses pembelajaran agama tidak akan terlaksana dengan baik mas,,tapi guru disini kreatif mas, semua mempunyai Pendekatanyag di siapakan sebelum mengajar, seperti setrategi CTL itu tadi"

Selain itu dengan cara membangun minat, penerapan Pendekatan CTL di madrasah Tsanawiyah Muhammadiyah Sejangkung juga dilaksanakan dengan memberikan konsep belajar dimana guru menghadirkan dunia nyata kedalam kelas sehingga mendorong siswa untuk membuat hubungan antara pengetahuan yang dimiliki dengan penerapannya dalam kehidupan sehari-hari seperti yang telah dijelaskan lagi oleh ibu bapak Wardi selaku guru bidang

${ }^{19}$ Wardi, 'Hasil Wawancara'. 
studi Qur'an Hadist di madrasah Tsanawiyah Muhammadiyah Sejangkung, sebagai berikut:

"Selain membangun minat pada siswa, penerapan CTL yang kami lakukan adalah dengan memberikan konsep belajar dimana guru menghadirkan dunia nyata kedalam kelas, misalnya dalam salah satu Bab tentang tata cara beribadah, akhalak terpuji, dan tatkrama kepada orang tua, maka setiap siswa diwajibkan mengikuti sholat dzuhur berjamaah, jadi semua anak terbiasa baik di rumah maupun di Sekolah. ${ }^{20}$

Jadi, dalam proses pembelajaran guru harus memperhatikan secara intensif terhadap berjalannya proses pembelajaran agar dapat berlangsung dengan baik dan sesuai dengan tujuan yang telah ditetapkan. Salah satunya yang dilakukan guru Qur'an Hadist di madrasah Tsanawiyah Muhammadiyah Sejangkung adalah bagaimana upaya mereka dalam menumbuhkan dan membangun minat yang besar pada siswa terhadap pelaksanaan dan penerapan pendidikan Qur'an Hadist dalam keseharian.

\section{Prinsip}

kesaling-bergantungan mengajarkan bahwa segala sesuatu di alam semesta saling bergantung dan saling berhubungan. Dalam CTL prinsip kesalingbergantungan mengajak para pendidik untuk mengenali keterkaitan mereka dengan pendidik lainnya, dengan siswasiswa, dengan masyarakat dan dengan lingkungan. Prinsip kesaling- bergantungan mengajak siswa untuk saling bekerjasama, saling mengutarakan pendapat, saling mendengarkan untuk menemukan persoalan, merancang rencana, dan mencari pemecahan masalah. Prinsip diferensiasi merujuk pada dorongan terus menerus dari alam semesta untuk menghasilkan keragaman, perbedaan dan keunikan. Dalam CTL prinsip diferensiasi membebaskan para siswa untuk menjelajahi bakat pribadi, memunculkan cara belajar masing- masing individu, berkembang dengan langkah mereka sendiri.

Prinsip pengaturan diri menyatakan bahwa segala sesuatu diatur, dipertahankan dan disadari oleh diri sendiri. Prinsip ini mengajak para siswa untuk mengeluarkan seluruh potensinya. Mereka menerima tanggung jawab atas keputusan dan perilaku sendiri, menilai alternatif, membuat pilihan, mengembangkan rencana, menganalisis informasi, menciptakan solusi dan dengan kritis menilai bukti.

Berdasarkan hasil penelitian dengan menggunakan metode wawancara dan Observasi, bahwasanya pelaksanaan pembelajaran Qur'an Hadist di madrasah Tsanawiyah Muhammadiyah Sejangkung telah mengacu pada tata tertib maupun aturan yang telah ditetapkan dalam setiap kegiatan atau proses pembelajaran dalam suatu lembaga pendidikan, diantaranya proses pembelajaran dengan mengacu pada kurikulum maupun silabus dari masingmasing materi pelajaran yang telah ditetapkan oleh pemerintah. Sehingga dari pihak sekolah tinggal mengolah serta membuat program serta rencana pembelajaran dengan tetap mengacu pada kurikulum maupun sillabus yang ada, dan untuk selanjutnya mengenai cara penyampaiannya dapat dikembangkan sendiri oleh masing-masing guru dalam mengajar di dalam maupun luar kelas, Sesuai dengan penjelasan bapak Wardi selaku guru bidang studi Qur'an Hadist.

\footnotetext{
${ }^{20}$ Wardi.
} 
"Mengenai masalah model yang mudah dilupakan, tetapi dapat pembelajaran yang digunakan, itu sudah menjadi kewajiban bagi guru masing-masing mata pelajaran untuk menyesuaikan dengan kurikulum. Yakni menggunakan tiga Pendekatanpembelajaran (konvensional, CTL, dandiskusi/praktek), jadi guru harus benar-benar mempersiapakan betul tentang setrategi apa yang nanti disiapkan waktu mengajar" disimpan dalam memori jangka panjang sehingga akan dihayati dan diterapkan dalam tugas pekerjaan, jadi menurut saya pembelajaran ini sangat menunjang keberhasilan siswa dalam belajar. Jadi dalam pembelajaran ini guru harus mampu menggerakan siswa untuk siswa untuk mandiri mas. $^{21}$

Sementara itu bapak Wardi selaku guru

Pernyataan tersebut didukung juga dengan penjelasan dari bapak Hendra selaku Kepala Sekolah di Qur'an Hadis, yaitu:

"Penerapan Pendekatanyang selama ini sudah dilakukan pada pelajaran, memang mengacu pada kurikulum yang telah disesuaikan dengan tiga al qur'an hadist juga menambahkan, berikut wawancaranya:

Pendekatanpembelajaran sekolah ini, kemudian dalam upaya meningkatkan mutu pembelajaran, guru dituntut harus pandaipandai menyesuaikan dengan keadaan siswa dan sesuai dengan materi sub bab yang sedang diajarkan. Dan tidak harus dengan penerapan Pendekatanyang selalu monoton. Ya anak- anak biar tidak bosan dan yang pasti bisa mengamalkan apa yang diajarkan guru.

Dalam waktu yang berbeda peneliti mengadakan observasi di dalam kelas dan selanjutnya wawancara kepada bapak Zinudin beliau mengatakan bahwa:

Contextual Teaching and Learning (CTL) adalah sistem pembelajaran yang cocok dengan kinerja otak, untuk menyusun pola-pola yang mewujudkan makna, dengan cara menghubungkan muatan akademis dengan konteks kehidupan sehari-hari peserta didik. Hal ini penting diterapkan agar informasi yang diterima tidak hanya disimpan dalam memori jangka pendek,

CTL (contekstual teaching and learning) kontekstual menekankan kepada proses keterlibatan langsung siswa untuk menemukan materi, artinya proses belajar di orientasikan pada proses pengalaman secara langsung. Proses belajar dalam konteks ini tidak mengharapkan agar siswa hanya menerima pelajaran, akan tetapi proses mencari dan menemukan sendiri materi pembelajaran. CTL mendorong agar siswa dapat menemukan hubungan antara materi yang di pelajari dengan situasi kehidupan nyata, jika dikaitkan dalam semua pelajaran, pembelajaran ini sangat bagus jika di terapkan dan membantu guru dan siswa dalam proses belajar mengajar mas,,, karena mengajari siswa untuk mandiri dan mencari penglaman baru.

Bapak Hendra, selaku kepala sekolah juga mengatkan bahwa:

Pembalajaran ini adalah dengan cara Melaksanakan pengajaran dengan selalu mendorong siswa untuk mengkaitkan apa yang sedang dipelajari dengan pengetahuan/pengalaman sebelumnya dan fenomena kehidupan sehari-hari, serta

${ }^{21}$ Zainudin, 'Wawancara' (Sejangkung, 2019). 
mendorong siswa untuk membangun kesimpulan yang merupakan pemahaman siswa terhadap konsep atau teori yang sedang dipelajarinya. Dan pada pelaksanaanya tidak terlalu sulit untu di terapkan. Dalam setrategi pembelajaran tidak hanya menuntut siswa menghafalakan fakta, konsep, generalisasi, tetapi sebuah Pendekatanyang mendorong siswa untuk mengkonstruksikan pengetahuan dibenak mereka sendiri, jadi denga adanya pembelajaran contekstual teaching and learning (CTL) dampak bagi siswa, siswa lebih mengerti dan mengalami sendiri dalam faktanya, tidak hanya sekedar menghafal dan belajar materi tetapi siswa mampu berfikir dan memperdayakan dirinya sendiri. ${ }^{22}$

Berdasarkan observasi dan wawancara yang di uraikan peneliti di atas, dapat diambil kesimpulan bahwa Pendekatanyang ditekankan pada pembelajaran Qur'an Hadist di Hasil wawancara dengan bapak Wardi selaku guru Qur'an Hadist madrasah Tsanawiyah Muhammadiyah Sejangkung. adalah penerapan pembelajaran contextual teaching and learning (CTL) karena pembelajaran tersebut sesuai dengan kondisi dan keaadaan siswa.

Di samping itu, yang sangat menentukan keberhasilan pencapaian tujuan pembelajaran, yaitu memilih salah satu pendekatan pembelajaran yang tepat dalam

22 Hendra, 'Wawancara' (Sejangkung, 2019).

23 Masnur Alam, 'Penerapan Model Contextual Teaching and Learning (Ctl) Pada Pembelajaran Pai Di Man 1 Sungai Penuh', Tarbawi: Jurnal Ilmu Pendidikan, 14.1 (2018), 77 <https://doi.org/10.32939/tarbawi.v14i1.258>. pembelajaran Pendidikan Agama Islam, di antaranya adalah melalui Pendekatan contextual teaching and learning (CTL). Dengan penerapan pendekatan kontektual murid menjadi lebih aktif, responsif dalam menggunakan pengetahuan dan keterampilan dalam kehidupan nyata sehingga siswa termotivasi tinggi untuk belajar. $^{23}$ Dengan menggunakan beberapa model pembelajaran tersebut, maka guru mata pelajaran pendidikan agama Islam dapat menerapkan Pendekatan yang efektif dan efisien. Disamping itu dalam penerapan saintifik dalam Pembelajaran Pendidikan Agama Islam perlu dilakukan berbagai macam pendekatan pembelajaran yang sesuai dengan tujuan pembelajaran yang diinginkan ${ }^{24}$

\section{Implikasi Penerapan Pendekatan Pembelajaran Contextual Teaching and Learning (CTL)}

Madrasah Tsanawiyah Muhammadiyah Sejangkung guru mata pelajaran Qur'an Hadist adalah figur seorang guru yang memiliki sifat terbuka, dinamis dan komunikatif. Sehingga beliau tetap dihormati sebagai seorang guru dan dicintai sebagai seorang yang bisa memberi masukan di bidang agama, sehingga mudah untuk mensosialisasikan penggunaan srtategi CTL.

Berdasarkan wawancara dan observasi kepada bapak Wardi selaku guru Qur'an Hadist, beliau menjelaskan sebagai berikut:

'Dengan adanya pembelajaran contekstual teaching and learning (CTL)

24 Irna Andriati, Zulfani Sesmiarni, and Armanida Armanida, 'Implementasi Pendekatan Scientific Pada Mata Pelajaran Pendidikan Agama Islam Di Sekolah Dasar', Journal Educative: Journal of Educational Studies, 2.2 (2017), 145-54. 
siswa lebih di tekankan Memperbaiki kebiasaan sehari-hari dalam PBM, yaitu dari siswa dipaksa menerima dan menghafal kearah Pendekatanpembelajaran yang berpihak dan memberdayakan siswa. Berawal dari pembelajran ini maka akan lebih terbiasa untuk melakukan dan memaksakan diri tentang pelajaran apa yang di peroleh oleh bapak ibu guru.

Dalam pengamatan peneliti guru Qur'an Hadis dalam menjalankan roda pendidikan di madrasah Tsanawiyah Muhammadiyah Sejangkung sangat efektif. Semua komponen yang ada mulai dari silabus, maupun persiapan sebelum mengajar, sudah tersiapkan secara teratur untuk keperluan kelancaran proses belajar mengajar dan para siswa sendiri mendukung sehingga dalam perkembangannya beliau tidak terlalu mengalami kesulitan menerapkan Pendekatan pembelajaran contextual teaching and learning (CTL).

Sebagai seorang guru Qur'an Hadist, maka dalam lembaga pendidikan memiliki peran yang sangat penting dan strategis yang digunakan harus tepat tanpa ada pengaruh yang negatif. Dari hasil observasi dan wawancara yang peneliti lakukan secara mendalam di madrasah Tsanawiyah Muhammadiyah Sejangkung dapat kami paparkan tentang dampak yang di rasakan dalam melaksanakan Pendekatan pembelajaran contextual teaching and learning (CTL). Adapun beberapa dampak dari penerapan pembelajaran contextual teaching and learning diantaranya:

a. Dampak terhadap siswa

Di dalam pendidikan, siswa adalah obyek yang harus dididik dan dikembangkan. Sedangkan Guru sebagai sebagai salah satu faktor terpenting yang akan bertanggung jawab dalam membentuk moral dan akhlak siswa. Terutama penerapan Pendekatanpembelajaran CTL dalam pembelajaran agama Islam agar dapat meningkatkan mutu pendidikan serta siswa mampu menerapkannya dalam kehidupan sehari-hari. Sebagaimana dijelaskan bapak Wardi, selaku guru Qur'an Hadist, sebagai berikut:

“Saya sebagai guru Qur'an Hadist harus bisa mengoptimalkan sumber daya manusia yang ada yaitu siswa. Saya memberikan bimbingan kepada semua siswa dengan menggunakan berbagai model strategi, agar SDM siswa dapat dioptimalkan termasuk salah satunya Pendekatancontextual teaching and learning dengan Pendekatantersebut diharapkan siswa bisa lebih aktif dan memiliki pemahaman yang merata sehingga dapat mendorong siswa untuk terus maju dan semangat".

b. Dampak terhadap guru Qur'an Hadis

Keberhasilan pendidikan Qur'an Hadist di sekolah sangat ditentukan oleh penggunaan model Pendekatanyang di terapkan seorang guru bidang studi akidah kahlak di sekolah tersebut. Peningkatan hasil dan prestasi hasil belajar siswa dapat dilakukan dengan penggunaan contextual teaching and learning (CTL) yang utuh.

Sebagaimana dijelaskan oleh bapak Wardi selaku guru Qur'an Hadist di madrasah Tsanawiyah Muhammadiyah Sejangkung menganai pengaruhnya terhadap guru, sebagai berikut:

"Semenjak saya terapkan Pendekatan pembelajaran contextual teaching and learning, menjadi kewajiban seorang guru untuk menemukan dan berfikir dalam memaksimalkan belajar siswa, namun itu wajar dan sangat berpengaruh yaitu menjadi lebih efisiennya proses pembelajaran 
dan sangat berbeda dengan model konvensional yang mana saya harus menerangkan secara detail sehingga menyita banyak waktu. Jadi jika setrategi ini bisa dimaksimalkan maka akan sesuai dengan tujuan.

Berdasarkan hasil observasi dan wawancara yang di jelaskan di atas dapat diambil kesimpulan bahwa pengaruh penerapan model Pendekatancontextual teaching and learning di sekolah selalu mengontrol proses berlangsungnya aktivitas pembelajaran dan memberikan hasil yang nampak pada perubahan sikap siswa yang semakin membaik. Karena itu tak lepas dari hakekat pembelajaran contextual teaching and learning yaitu merupakan suatu prinsip pembelajaran yang memungkinkan.

\section{Faktor pendukung dan penghambat Pembelajaran Contextual Theaching and Learning (CTL)}

Sebelum membahas tentang faktor pendukung dan penghambat Pembelajaran contextual theaching and learning (CTL), bapak Hendra, selaku Kepala madrasah Tsanawiyah Muhammadiyah Sejangkung, sebagai berikut:

Pembelajaran yang kompeten memenuhi tiga ranah, yaitu kognitif, afektif dan, Psikomotor, ketiga aspek tersebut harus di kembangkan secara terpadu dalam dalam setiap bidang kegiatan pembelajaran. Guru dapat memilih bagian mana yang cocok untuk aspek kognitif, afektif, maupun psikomotor melalui penerapan model ini, di harapkan dapat membantu para guru dalam mengarahkan peserta didik untuk menjadi manusia yang benar-benar mempunyai kualitas belajar yang kuat yang di hiasi dengan akhlak yang mulia dalam kehidupan sehari-hari, salah satu caranya hal tersebut adalah dengan memakai pembelajaran contekstual teaching and learning (CTL), jadi pembelajaran ini tetap di perlukan mas. Meskipun tidak di terapkan dalam setiap harinya.

\section{Faktor pendukung dan penghambat pembelajaran Kontextual Teaching and Learning}

Faktor Pendukung Penerapan Pendekatanpembelajaran contextual teaching and learning (CTL) Upaya kepala sekolah dengan mengikut sertakan guru aqidah akhlak dalam sebuah musyawarah guru mata pelajaran (MGMP) atau mengikut sertakan dalam Work shop (Pelatihan), dan memberikan bahan-bahan berupa buku bacaan tentang Pendekatan Contextual Teaching and Learning yang juga merupakan faktor pendorong dalam pelaksanaan Pendekatancontextual teaching and learning. Sebagaimana dijelaskan oleh bapak Hendra, selaku Kepala madrasah Tsanawiyah Muhammadiyah Sejangkung, sebagai berikut:

"Banyak upaya telah kami lakukan untuk meningkatkan wawasan guru dalam pelaksanaan contextual teaching and learning (CTL), di dalam pembelajaran Qur'an Hadist, salah satunya adalah berusaha mengikutsertakan para guru, terutama guru Qur'an Hadist untuk mengikuti musyawarah guru mata pelajaran (MGMP) yang berhubungan dengan pelaksanaan Pendekatan contextual teaching and learning (CTL), dan pelatihan-pelatihan agar guru bisa memahami dengan segera tentang contextual teaching and learning (CTL), sehingga harapan kami kompetensi yang dimiliki para guru di madrasah Tsanawiyah Muhammadiyah Sejangkung dapat menjadikan pendukung dalam meningkatkan mutu atau kualitas siswa yang merupakan tujuan yang diharapkan dalam 
proses belajar mengajar, terutama dalam pembelajaran Qur'an Hadist di madrasah Tsanawiyah Muhammadiyah Sejangkung."

Setiap penerapan sesuatu model pembelajaran pasti mempunyai faktorfaktor salah satunya adalah faktor pendukung dan penghambat begitu juga dalam penerapan Pendekatan contextual teaching and learning di madrasah Tsanawiyah Muhammadiyah Sejangkung juga banyak mengalami kendala dari berbagai faktor. Baik faktor pendorong dan juga faktor penghambat didalam pelaksanaan penerapan Pendekatancontextual teaching and learning (CTL). Sebagaimana dijelaskan oleh bapak Wardi selaku guru pendidikan Qur'an Hadist, sebagai berikut:

"selama ini salah satu faktor yang mendukung adalah perubahan kurikulum yang semakin disempurnakan. Kurikulum yang semula menggunakan kurikulum 2004 (KBK) kini menjadi menjadi kurikulum 2006 (KTSP) yang kita pakai hingga saat ini. Seiring berubahnya kurikulum maka kami dituntut untuk mengikuti pelatihanpelatihan dan juga memperbanyak bahan bacaan tentang perkembangan kurikulum. Dimana kurikulum tersebut banyak membawa perubahann dalam pendidikan, sehingga menuntut guru untuk bisa memaksimalkan proses belajar mengajar yang selaras dengan diterapkannya contextual teaching and learning."

Jadi menurut guru Qur'an Hadist yang menjadi faktor utama adalah terjadinya perubahan sistem kurikulum oleh mentri pendidikan di indonesia. Dan ini yang menjadi fokus guru agama untuk selalu mencari inovasi terhadap cara dalam mengajar atau menyampaikan sebuah ilmu yang salah satunya adalah dengan menerapkan model

Pendekatanpembelajaran contextual teacbing and learning dan bimbingan yang dilakukan di sekolah tidak terfokus pada tenaga pendidik atau guru saja tetapi juga pada peningkatan prestasi belajar dan penanaman akhlak yang mulia pada siswa. Penanaman akhlak ini dilakukan semua guru dengan menunjukkan sikap dan prilaku sehari-hari yang mencerminkan muslim yang beriman dan bertaqwa. Karena itu adalah inti dari pembelajaran Qur'an Hadist.

Dalam rangka mengembangkan madrasah Tsanawiyah Muhammadiyah Sejangkung yang berkualitas maka perlu penciptaan iklim yang kondusif khususnya di internal madrasah sebagai faktor pendukung selanjutnya. Sebagaimana dijelaskan bapak Wardi selaku guru pendidikan Qur'an Hadist sebagai berikut: "Sebagai guru agama, dalam menerapkan Pendekatanapapun juga membutuhkan iklim dan suasana lingkungan yang tenang. Dan selama dalam penerapan Pendekatan contextual teaching and learning alhamdulillah suasana lingkungan begitu mendukung, kita tahu bahwa pembelajaran dengan menggunakan model PendekatanCTL ini tidak hanya belajar di dalam kelas, tapi juga di luar kelas."

Dengan terciptanya suasana yang terkendali akan membuat iklim di madrasah Tsanawiyah Muhammadiyah Sejangkung menjadi kondusif dan ini sangat membantu sekali dalam mensukseskan pelaksanaan model Pendekatancontextual teaching and learning (CTL).

Faktor Penghambat Pelaksanaan Pendekatan Contextual Teaching and Learning (CTL)

Kurangnya pemahaman terhadap siswa yang kurang mampu terhadap suatu penerapan Pendekatanpembelajaran seperti 
yang dijelaskan oleh bapak Wardi selaku guru pendidikan aqidah akhlak sebagai berikut:

"perbedaan tingkat pemahaman murid kadang tidak cukup dengan penerapan model Pendekatan contextual teaching and learning (CTL). ini memaksa seorang guru harus mencari inovasi atau cara lain untuk mengatasi masalah tersebut, misalnya dengan menggunakan Pendekatan tutor sebaya"

Hal ini ditambahkan oleh salah satu guru bahwa guru agama dalam penerapan suatu model pembelajaran harus selalu menekankan kepada seluruh siswa untuk bersungguh-sungguh dalam belajar, karena belajar merupakan sebuah amanah yang wajib dipertanggung jawabkan. Seorang guru yang efektif dan baik adalah guru yang memiliki pedoman taat hukum dan peraturan-peraturan serta melaksanakannya dengan baik termasuk peraturan-peraturan yang baru.

Sebagai konsekwensi kenyataan di atas guru Qur'an Hadist di madrasah Tsanawiyah Muhammadiyah Sejangkung selalu menampung alternatif-alternatif yang masuk dari kemajuan Informasi pendidikan yang selalu berkembang dengan berbagai pertimbangan dalam argumentasinya masing-masing. Tetapi hal ini bukan berarti beliau tidak mempunyai pendirian yang teguh, justru orang yang berpendirian teguh dan mempunyai wibawa ia harus selalu mencari dan memaksimalkan proses belajar mengajar. Dari gambaran di atas menjadi bukti bahwa penerapan pembelajaran contextual teaching and learning (CTL) di sekolah madrasah Tsanawiyah Muhammadiyah Sejangkung selain sebagai salah satu inovasi dalam proses belajar mengajar juga banyak membawa perubahan terhadap perkembangan prestasi siswa.

\section{Kesimpulan}

Contextual Teaching and Learning (CTL), merupakan salah satu faktor yang sangat menentukan. Guru yang kreatif dalam menggunakan metode pembelajaran maupun dalam penggunaan media adalah sesuatu yang pokok dalam penerapan Contextual Teaching and Learning (CTL). Model pembelajaran CTL, dapat membantu meningkatkan hasil belajar siswa karena model pembelajaran CTL ini lebih memfokuskan pada pemahaman serta menekankan pada pengembangan minat dan pengalaman siswa dalam kehidupan sehari-hari, bukan hanya sekedar hafalan sehari-hari. Sehingga dengan pembelajaran CTL ini siswa diharapkan dapat berfikir kritis dan terampil dalam memproses pengetahuan agar dapat menemukan dan menciptakan sesuatu yang bermanfaat bagi dirinya sendiri dan orang lain.

Kurangnya keterampilan guru dalam memilih metode pembelajaran sehingga contextual teaching and learning /CTL menjadi terhambat dan tidak sesuai dengan apa yang menjadi tujuan. Guru merasa kesulitan dalam menata ruang tempat proses belajar mengajar berlangsung, karena siswa yang ada terlalu banyak tetapi, kalau siswanya sedikit hal ini tidak menjadi masalah. Kurangnya keterampilan guru dalam memilih metode pembelajaran sehingga contextual teaching and learning /CTL menjadi terhambat dan tidak sesuai dengan apa yang menjadi tujuan. 


\section{Daftar Pustaka}

\section{Journal Ilmiah}

Alam, Masnur, 'Penerapan Model Contextual Teaching and Learning (Ctl) Pada Pembelajaran Pai Di Man 1 Sungai Penuh', Tarbawi: Jurnal Ilmu Pendidikan, $14.1 \quad$ (2018), 77 $<$ https://doi.org/10.32939/tarbawi. v14i1.258>

Andriati, Irna, Zulfani Sesmiarni, and Armanida Armanida, 'Implementasi Pendekatan Scientific Pada Mata Pelajaran Pendidikan Agama Islam Di Sekolah Dasar', Journal Educative: Journal of Educational Studies, 2.2 (2017), 145-54

Gunawan, Zaini, and Ainur Rahmah, 'PENDEKATAN CONTEXTUAL TEACHING AND LEARNING DAN APLIKASINYA DALAM PEMBELAJARAN PAI DI SEKOLAH', PEDAGOGIK: Jurnal Pendidikan, 6.2 (2019), 557-92

Hadiyanta, Nur, Penerapan Model Pembelajaran Contextual Teaching and Learning (CTL) Untuk Meningkatkan Hasil Belajar PKn', Jurnal Kependidikan: Penelitian Inovasi Pembelajaran, 43.1 (2013)

Panjaitan, Musepini Apriliani, and Mufti Sudibyo, 'Perbandingan Hasil Belajar Siswa Yang Diajar Dengan Strategi Pembelajaran Contekstual Teaching Learning (CTL) Dengan Yang Diajar Dengan Strategi Pembelajaran Ekspositori Pada Materi Sistem Transportasi Darah SMP Swasta PAB 9 TP 2014/2015', Jurnal Pelita Pendidikan, 3.4 (2015)

Widarti, Sri, Endah Peniati, and Priyantini Widiyaningrum, 'Pembelajaran Gallery Walk Berpendekatan Contextual Teaching Learning Materi Sistem Pencernaan Di Sma', Journal of Biology Education, 2.1 (2013)

\section{Buku}

Bogdan, R, and S K Biklen, Qualitative Research for Education: An Introduction to Theory and Methods (Allyn and Bacon, 1992)

$<$ https://books.google.co.id/books?i $\mathrm{d}=1 \mathrm{~B} 4 \mathrm{mAQAAIAAJ}>$

John M. Echols dan Hasan Syadily, Kamus Inggris Indonesia, Jakarta, Gramedia. (Jakarta: Gramedia, 2000)

Sugiyono, Metodologi Penelitian Pendidikan; Pendekatan Kuantitatif Kualitatif Dan ReD (Bandung: Alpabeta, 2009) -, Menjadi Guru Profesional (Bandung: Remaja Rosda Karya, 2005)

Sanjaya, Wina, Pembelajaran Dalam Implementasi Kurikulum Berbasis Kompetensi (Kencana, 2006) $<$ https://books.google.co.id/books?i $\mathrm{d}=$ QL9hNwAACAAJ $>$

Suwito, Sejarah Sosial Pendidikan Islam (Kencana, 2005) <https://books.google.co.id/books?i $\mathrm{d}=$ zsyCNAAACAAJ $>$

Usman, M U, Menjadi Guru Profesional (Remaja Rosdakarya, 1999) <https://books.google.co.id/books?i $\mathrm{d}=$ enpZNwAACAAJ $>$

Mulyasa, E, Kurikulum Yang Disempurnakan, Pengembangan Standar Kompetensi Dan Kompetensi Dasar (Bandung: Remaja Rosda Karya, 2006)

Laila, Noor Alfu, 'Pengaruh Pendekatan Ctl (Contextual Teaching and Learning) Terhadap Hasil Belajar Membaca Pemahaman Bahasa Indonesia Siswa Kelas Iv Sd', Jurnal Cakrawala Pendidikan, $3.3 \quad$ (2009) $<$ https://doi.org/10.21831/cp.v3i3.3 01>

McMillian, J., and S. Schumacher, Research in Education: A Conceptual Introduction (4th Edition). ., Pearson Education Limited (Scott, Foresman, 1997) $<$ https://books.google.co.id/books?i $\mathrm{d}=7 \mathrm{~J} 7 \mathrm{kAAAACAAJ}>$ 
Zayadi, Ahmad, and Abdul Majid, Pembelajaran Pendidikan, 2011

\section{Wawancara}

Wardi, (Guru Qur'an Hadist Madrasah Tsanawiyah Muhammadiyah Sejangkung) Wawancara, \{Sunday, 12 Agustus 2019\}

Hendra, (Kepala Sekolah Madrasah
Tsanawiyah Muhammadiyah Sejangkung) Wawancara, \{Sunday, 12 Agustus 2019\}

Zainudin, (Guru PAI Madrasah Tsanawiyah Muhammadiyah Sejangkung) Wawancara, \{Sunday, 12 Agustus 2019\} 